\title{
An impact study of the Village Savings and Loan Association (VSLA) in Nigeria
}

\author{
Chinwe U. Nnama-Okechukwu ${ }^{1}$, Uzoma O. Okoye ${ }^{1}$, Christy Obikeguna ${ }^{1}$, Chinyere E. \\ Onalu ${ }^{1}$, Agha A. Agha ${ }^{1}$, Jacinta Eneh ${ }^{1}$, Angela I Ogbu ${ }^{2}$, Eghosa A. Erhunwunse ${ }^{3}$, \\ Anthony A. Nwanze ${ }^{4}$ \& Taiwo Okunsanya ${ }^{5}$ \\ ${ }^{1}$ Department of Social Work, University of Nigeria, Nsukka, Nigeria, \\ ${ }^{2}$ Department of Sociology, Benson Idahosa Universty, Edo Nigeria \\ ${ }^{3}$ National Director, SOS Children's Villages Nigeria \\ ${ }^{4}$ Programme Director, SOS Children's Village Programme Ogun, Nigeria \\ ${ }^{5}$ School of Nursing Science, University of Nigeria Nsukka. \\ Email:Christy.obikeguna@unn.edu.ng
}

\begin{abstract}
Background: The VSLA is an emerging movement of savings that promotes entrepreneurship development in rural communities; it has supported the growth of small and medium enterprise in rural communities as well as helped families at risk to enhance family well-being. There are however scare empirical studies on VSLAs in Nigeria, hence impact and learning is often not in the public domain.

Method: In this article, we endeavored to clarify concept and present result from a qualitative study using Focus Group Discussion (FGD) for 48 families who participated in the SOS Children's Villages Nigeria Family strengthening from 20I0-20I5.

Result: Overall result suggest that VSLA is a programme intervention that is successful and sustainable. Results revealed that $70 \%$ of the families in the programme attained self-reliance within the project life span

Conclusion: The results are discussed in relation to entrepreneurship development and need for social workers to create awareness on VSLA in rural communities in Nigeria
\end{abstract}

Keywords: Entrepreneurship development, savings groups, social work, SOS Children's Villages Nigeria, sustainability, VSLA.

\section{Introduction}

Informal savings group and formal financial microfinance institutions are credit facilities established to reduce poverty and encourage entrepreneurship development in rural communities in the global south. Informal savings and credit groups in different parts of the global south as indicated in studies have provided access to credit for the rural poor and enhanced family well-being (Sibomana \& Shkla, 2016; Uruakpa, 2018). Apart from providing access to credit, informal saving groups is supporting the growth of small and medium enterprise in rural communities as well as promoting income generating activities to help poor families grow and own small business. Informal savings and credit groups like "susus" of Ghana and "tontines" in West Africa are among the oldest savings and credits in Africa that have provided access to credit to the rural poor (Appiah \& Michael, 2014). There is also the 'Isusu' of Nigeria which is a common informal credit and savings groups among market women and other small enterprise which have improved family well-being through income generating activities (Otto \& Ukpere,
20II). Other informal saving groups such as the Rotating Savings and Credit Associations (ROSCAs), Accumulating Savings and Credit Association (ASCRAs), Savings and Cooperative Society Organization (SACCO), and the likes have also impacted positively on the rural poor, provided access to credit to own business and improved family well-being Jackson, 2016; Karlan, Savonittes, Thuysbaert, \& Udry,2017; Yusuf, ljaiya \& ljaiya, 2009). Despite studies that revealed that these informal savings and credit groups have helped poor rural populace to raise small capital to start small business and enhance family well-being, there are concerns with this saving groups. Concerns with sustainability, financial inclusion and training on entrepreneurship development is often lacking in these saving group.

Aside sustainability and capacity building for participants, most of these informal savings group just like the formal financial microfinance instructions operate on a rigid structure often excluding some people who are not credit worthy to participate in the process. For financial inclusion, formal 
microfinance institution was initiated to provide credit facility to the rural poor as a means of reducing poverty and encouraging entrepreneurship development. Formal microfinance institutions just like other informal savings and credit groups however has it peculiar challenges as it failed to reach remote and rural areas thus leading to increasing level of poverty, unemployment and labour migration in most rural communities in Africa (Lonborg \& Rasmussen, 2014). While pointing out the challenges associated with formal microfinance institutions, Allen and Panatta (20I0) aver that microfinance institutions have urban orientation and access to rural areas remains a challenge due to poor road networks thus making their services unavailable to the rural poor. Besides, it is often not cost effective for microfinance institutions to reach the rural poor due to the low population density of rural communities (Brannen \& Shechan-Connor, 2012). To address this mounting challenges with formal and micro finance institutions, the Village Savings and Loan Association (VSLA) brought a new innovation in saving and credit groups which is more sustainable for the rural poor, provides training on entrepreneurship development and operates on a flexible structure (Catholic Relief Services, 2017; CARE, 2013:)

The Village Savings Loan Association (VSLA) is a savings and credit intervention programme that has gained increased popularity in developing countries around the world due to its impact on the rural poor especially women (Karlan, et al., 20I7; Sibomana \& Shkla, 2016). Unlike other saving and credit groups, the VSLA has been found to be a highly standardized emerging savings group which is flexible, provides training on business skills, promotes entrepreneurship and more sustainable for rural communities (Ksoll, Lilledor, Lonborg \& Rasmusswn, 2016; Musansakilwa, Tembo, Zula \& Wamaluma, 2017; Musinyuzi, 2016). For instance, studies have shown that though an emerging movement of savings that promotes entrepreneurship development in rural communities; it has sustained the growth of small and medium enterprise in rural communities as well as helped families at risk to enhance family wellbeing (Jackson, 2016; Tamim, 2015). Many studies have showed the impact of the VSLA in terms of family wellbeing, improved nutrition, poverty reduction, entrepreneurships development, provision of basic need (Karlan, etal., 2017; Tamim, 2015). There are notwithstanding few challenges which have been noted in studies that if improved on can enhance the spread of VSLA in rural communities and promote achievement of not just goal one but also other key areas in the sustainable development goals.

While there are vast empirical studies on the impacts of the Village Savings and Loan Association as a means of poverty eradication and meeting the welfare needs of the rural poor in many communities in Asia (Karlan etal., 2017; Ksoll et al., 2016; Tamin, 2015), and Africa (Abubakari et al., 2014; Musansakilwa et al., 2017; Musinyuzi, 2016, Jackson, 2016), there are scare empirical studies on VSLA in Nigeria. Though VSLA is gradually spreading in different parts of the country through various actors such as Non-governmental and international donor organization, impact is not much as empirical evidence are lacking. Majority of studies in Nigeria primarily focus on other informal saving groups and on formal Micro Finance Institutions (MFIs) that provides micro-credit and micro-loans (Badiru, Yusuf \& Anozie, 2016; Ogunrinola, 20II; Otto \& Ukpor, 20I I; Yusuf, ljaiya \& ljaiya, 2009). To therefore place the impact of the VSLA in the public domain, the following research question will be answered in this study; (a) what impact does VSLA have on family wellbeing for study participants? (b) what role does the SOS Children's Villages Nigeria play in VSLA? (c) how does VSLA contribute to entrepreneurship development and what are the challenges for study participants?

\section{Literature review and theoretical framework}

Savings and credit groups around the globe are financial models that are often considered and used to deliver financial services to the rural poor as a means of poverty reduction, encouraging entrepreneurship development and improving family well-being. Entrepresnurishp development through saving groups have been viewed by studies as a means to reduce poverty and contribute to the achievement of goal one of the sustainable development goals (SDGs) (Breza \& Chandrasekhar, 2019; Beyene, 2018; Uruakpa, 2018). Sustainable Development Goal number one aimed to eradicate extreme poverty which is currently measure as people living on less than $\$ 1.25$ a day. This can be made possible by ensuring men and women, in particular the poor and vulnerable, have equal rights to economic resources, as well as access to basic service, ownership and control of natural resources (United Nations, 2016). This goal is however yet to be achieved as many countries in Sub-Saharan Africa are still under the heavy weight of poverty despite the World Bank report on poverty reduction in some regions around the world.

For instance, the World Bank (2019) report shows that while poverty rates have declined in all regions, progress has been uneven, given that two regions, East Asia and Pacific (47 million extreme poor) and Europe and Central Asia (7 million) have reduced extreme poverty to below 3 percent, achieving the 2030 target. Report revealed that majority of the 
global poor live in rural areas, are poorly educated, employed in the agricultural sector, and under 18 years of age. More than half of the extreme poor live in Sub-Saharan Africa as the number of poor in the region increased by 9 million, with 413 million people living on less than US\$1.90 a day in 2015, more than all the other regions combined (World Bank, 2019). The situation is not different in Nigeria which is referred to as the populous country in Africa. UNICEF annual report in 2017 reveled that although Nigeria has the largest economy in West Africa, over $64 \%$ of the population live below the poverty line., Gert and Kharas (20/8), also noted that Nigeria is rated as having the largest number of poor people globally. Majority of poor people in Nigeria reside in rural areas and have no means of generating income and often are excluded in formal financial service because they lack entrepreneurship skills. Studies show that most rural poor do not possess any form of entrepreneurship skills which is becoming a tool for poverty reduction (Uruakpa, 2018; Badero, 2016; Otto \& Ukpere,20II \& Adofu. Antai \& Allabi, 20l0). To promote entrepreneurship skills, there is need for proper engagement of the rural poor especially on income generation. Okoye (20I7) noted that many family problems originate from insufficient financial resources, while others may originate from misunderstanding about what things money should be spent on. Understanding the need for entrepreneurship development using VSLA can help in income generating activities thereby providing available financial resources that can meet family needs.

Entrepreneurship development in rural communities across the globe using the Village Savings and Loan Association (VSLA) is met with increasing attention by social workers and significant others in recent years. This is because there has been renewed interest in searching for financial models that can be used to deliver sustainable financial services to the rural poor in Africa and other developing parts of the world (Anyango, Esipisu, Opoku, Johnson, Malkamaki, \& Musoke,2007; Champchesnel, Fioekon,Sanda, Lavanr \& Maynns, 2017; Hinson,Oduro \& Cottrell, 2017). This search has been motivated by the failure of formal or centralized microfinance institutions to reach remote and rural areas thus leading to increasing level of poverty, unemployment and labour migration in most rural communities in Africa (Lonborg \& Rasmussen, 20I4). This challenge limits families especially those in rural communities from access to financial inclusion. The World Bank observed that from the 193.6 million families which are categorized as poor worldwide, only $47.8 \%$ were found to be in the range of reaching the formal financial institutions 4903 services. For Africa's poorest and most marginalized households, financial inclusion is often seen as a long way off. This is because few financial institutions exist in most rural communities, and where such institutions are available, they often have inappropriate products and services to offer the poor that they project to support (CARE, 20I3). The reality is that most extremely poor households have neither the assets nor the skills to interact with formal financial institution (Hendrick \& Chidiae, 20II). To address these shortcomings, Surmont (2017) noted that the Cooperative Association and Relief Everywhere (CARE) initiated the VSLA model of saving for rural communities in Africa. This is as a way encouraging financial inclusion by building financial assets and skills as well as promoting entrepreneurship development in rural communities. This savings model by CARE began through the promotion of a savings-led microfinance model, called Village Savings and Loans Associations (VSLA, 20I4). It was first initiated in Niger in I99I by CARE international

Since the initiation of the VSAL savings model by CARE, there has been documented evidence on the positive impact of the model in developing countries like Asia and Africa (Bruinc, Funmagali, Martin, Field \& Rutherford, 20I4; Ksoll et al., 2016; Musansakilwa et al., 2017). The VSL model has spread to at least 73 countries in Africa, Asia and Latin America, with over 12 million active participants worldwide. Thus, VSL model intends to provide the urban very poor and the rural poor with savings services as well as insurance and credit that can be delivered cost effectively, provide a secure place to save, the opportunity to borrow in modest amounts, easy to understand and transparent in its operations (VSL Associates, 2017). Karlan, et al., (2017) noted that many actors, including international donors, such as the Bill and Melinda Gates Foundation, and nongovernment organizations have pushed to create and expand VSLA groups. This is because of its grassroots and low-cost mechanism of providing financial services to the poor (Catholic Relief Services, 2017). The inspiration for VSLAs came from ROSCAs (Ksoll et al. 2016) with sustainability being the major focus. Unlike in ROSCAs, borrowers in VSLAs pay interest on loans to the group, which should encourage more savings by those with greater means while simultaneously discouraging borrowing for less productive purposes (Brannen \& SheehanConnor 2012). Whereas ROSCAs multiply without external facilitation, VSLAs only do so to a limited extent, thus requiring the facilitation of organizations such as Non-Governmental Organization (NGO) (Ksoll et al. 2016). 
The VSLA unlike microfinance institution is noninstitutional, community-based and accessible savings group model that embraces social support network in its movement of financial inclusion of the rural poor (VSLA, 2014). The VSLA consist of 15 to 30 people who come together to save a small amount every week for a period of one year usually called a cycle. Unlike some saving groups like SACCO and ROCHAs that are formally registered with the government and require some kind of rigorous bookkeeping, VSLA is more user friendly with less bureaucratic process for illiterate members. The model provides a poverty reduction approach to the economically disadvantaged, mostly women, to integrate methods of taking out loans and savings in their day to- day lives as a way to alleviate poverty and unemployment (Kesanta \& Andre, 2015). This is based on the belief that for the extremely poor, particularly women, the best approach is to begin by building their financial assets and skills through participation in savings groups rather than debt (Hendrick \& Chidiae, 20II). This is to build their confidence and promote their interest in saving for a sustainable development. This is supported by the Sustainable Livelihood Approach (SLA).

This study is anchored on the SLA. This SLA is built on participatory approaches and was developed in order to organize and improve organizations efforts to eliminate poverty (Atha, 2017). The sustainable livelihood approach was first introduced by Brundtland Commission on Environment and Development and has been used in programming by agencies such as CARE, UNDP, DFID and the likes. The approach uses a kind of integrated approach to community development by involving various stakeholders in its approach to sustainable livelihood for the rural poor. According to Krantz (200I), there are three insights into the sustainable livelihood approach which include the realization that while economic growth may be essential for poverty reduction, there is not an automation relationship between the two since it depends on the capabilities of the poor to take advantage of expanding economic opportunities. Furthermore, there is the realization that poverty is not a matter of low income but also includes other dimensions like illiteracy and lack of social services (Krantz, 200I). Finally, there is also the realization that the poor need to be involved in policy and project designs that will help address their needs. lan Scoones o

The SLA has value in addressing the constraints in poor people's livelihoods by seeing the poor not as victims, but as decision-makers with their own sets of priorities. That is why proponents of the SLA like lan Scoones sees it as including both social and material resources that people need to make living sustainable. The SLA is a successful instrument for empowerment of the poor, since it promises targeted assistance, better communication channels, and new possibilities for rural people. This has implication for social work practice especially with enhancing the problem solving and coping capacity of people and sustainable community development programmes. Social work as a professional service seeks to help people develop that coping capacity that will enable them be part of programme and projects that will promote their welfare. As professional services, social work is also geared toward working with vulnerable groups to identify and make efficient use of resources and opportunity within their environment that can improve their lot. Surmont (2017) noted that the SLA relies on the idea of community-driven development and is acclaimed for taking a holistic perspective in determining problems and opportunities for programme activities. This involves study of context; resources; institutions and organizations; livelihood strategies and livelihood outcomes. This approach is acclaimed for departing from the traditional income-centric view of livelihood promotion (Atha, 2017), to a broader field of sustainable development and indeed integrated rural development (Morse, McNamara, \& Acholo, 2009). This is with a view of bringing the natural, social and economic assets of rural communities to the level of development with social workers being actively involved in community assessment and resource mobilization.

The SLA was considered appropriate in the understanding of the VSLA because empowering people especially women will help economic participation of women and poverty reduction for a more sustainable development. This will equally reduce their dependency on the male partners thereby promoting their wellbeing and that of their family. This dependency makes them incapable of making life decisions concerning their wellbeing and predisposes them to endure mistreatments from their male partners. This is an area that social workers can help promote sustainable development goals by encouraging entrepreneurship development. Social workers can enhance the capacity of women through empowerment programmes that seek to aid them become self-reliant (Kiboro, Gakuru Misaro \& Mwangi, 2014). This can be achieved through emphasizing their inherent strengths and opportunities available to them. Social workers can also advocate for policies and programmes designed to eliminate poverty and promote the economic wellbeing of women, so that women can be empowered to take control of their lives (NnamaOkechukwu, Chukwu \& Ekoh, 20I7). 


\section{Data and methods}

\section{Study area}

The study area is SOS Children's Village Ogun Programme (SOS CVP Ogun), where the SOS Children's Villages Nigeria is implementing its programme. Ogun state is one of Nigeria's 36 states within the south west geo-political zone of the country with a total population of $3,728,098$ (National Population Commission, 2006). SOS CVP Ogun is located in Owu-ijebu in ljebu-east Local Government Area of Ogun State with its headquarter at Ogbere. Owu-ljebu is one of the eleven (II) political wards that makes up the Local Government, with SOS CVP Ogun working presently in five (5) of the eleven (II) political ward through the Family Strengthening (FS). This is in collaboration the Child and Family Development Imitative (CFDI) which is a Community Based Organization (CBO).

SOS Children's Villages Nigeria operates in four locations in the country namely SOS Children's Village Programme Lagos, SOS Children's Village Programme Ogun, SOS Children's Village Programme Abuja and SOS Children's Village Programme Plateau. In all these Programme locations, SOS Children's Villages Nigeria provides two forms of social support services. These are the alternative child care programme with a family-based care model for children who have lost parental care and the family strengthening as prevention mechanism against child abandonment for children at risk of losing parental care. Other programme includes education, health, and social centers where some are stand alone and full fledge intervention in some locations. In all these programme locations, there are VSLA in operation within few rural communities which is promoting savings culture for entrepreneurship development in rural communities.

\section{Sampling procedure}

The study design is an explorative research design which relied on qualitative research method. This was informed by the need to adequately capture the phases and nuances within families. The families that participated in the family strengthening programme from $2010-2015$ were recruited into the study. A total of 68 families participated in the family strengthening programme from 20I0-20I5. From the total number of families that participated in the programme, 48 families were selected to participate in this present study. Their selection was based on purposive cum convenient sampling procedure Fortyeight families were recruited from three selected communities (ljebu-lfe, ljebu-lkija and Owu-ljebu) out of the five communities (ljebu-Imushin, ljebu-Ife, ljebu-Itele. Ijebu-Ikija and Owu-ljebu) where the family strengthening programme was implemented.
Their selection was based on purposive cum convenient sampling procedure. The Community Based Organization ( $\mathrm{CBO}$ ) assisted in locating these families. Social workers and field officers at the programme location obtained a list of those willing to participate in the study. They also made effort to reach those willing and ready to participate in the discussion.

Six Focus Group Discussions [FGD] were held in all. Each session was made of 8 women. Women were used for the study because they offered themselves willingly to participate in the study. On the whole, 48 women from three communities participated in the FGD. This was through the help of members of Board of Trustees (BoT) of the CBO. Families selected were those that have participated in the VSLA from 2010-2015. Each of the families was contacted through their mobile numbers. During the call, informed consents, addresses and schedule for the FGD were sought from the respondents. The discussion sessions were conducted in Yoruba and Pidgin English language. Language used was based on the choice of the study participant. Majority of the women used for the study speak and understand the Yoruba language.

\section{Data collection}

Data was collected using a semi-structured FGD schedule. The discussion sessions were conducted in two major locations. For Owu-ljebu and ljebu-lkija, the discussion was conducted at the Owu-ljebu community hall which was the venue chosen by the participants. The community hall which is strategically located at the boundary of the two communities oftentimes served as the weekly meeting place for the VSLA group as well as the training center for their monthly parenting skill training class organized by the SOS Children's Villages Nigeria. The location was considered suitable by the participants due to its accessibility. Discussion with participants at the ljebuIfe location took place in a small church building owned by one of the members of the VSLA. The Church served a dual function for members of the VSLA group in that community; first as a weekly meeting venue for VSLA members and then also as a center for their monthly parenting skill training class organized by the SOS Children's Villages Nigeria.

The participant gave their oral consent with full knowledge of the aims of the research. The FGD was conducted in February 2016. Based on their permission, the discussions were recorded with a recording device, while a note-taker took notes. The discussion was held using the Yoruba language. A total of 6 FGD was held in all. Two FGD were held in ljebu-lfe while four FGD were held in Owu-ljebu community hall. Each group was made up of 8 
women and discussion with each came up on a weekly basis. This lasted for six weeks. A social worker and field officers from the SOS Children's Village programme Ogun location took notes and tape recorded the discussion respectively after obtaining permission from the VSLA group.

\section{Data analysis procedure}

In analyzing the qualitative process, the process began with careful recording of all sessions. The voice recordings were transcribed verbatim in indigenous languages in order to retain the original thoughts of the participants. The transcriptions were translated to English language by an expert from the Department of Mass Communication, University of Nigeria. The transcripts we generated from each of the FGD in the two locations were read for content validity by two of our research assistants. The transcribed discussions were compared to the recorded discussions by the researchers to ensure that original meaning of what participants said was retained.

\section{Results}

\section{Demographic characteristics of participants}

The study was conducted among families that participated in the SOS children's Villages Nigeria family strengthening programme from 20I0-20I5. Majority of the families in the programme $(53.8 \%)$ were above 56 years. Majority of the programme participants $(91 \%)$ were female. About $56 \%$ of the female study participants were widows or single parent households while almost $42 \%$ were grandparents headed households. A very small percentage of $2 \%$ are child-headed household. Expectedly, majority of the families $87.5 \%$ were Yoruba, since the study was conducted in ljebu, Ogun State, south western part of Nigeria where the people are predominantly Yoruba's. Other study participants $12.5 \%$ were from the South-South and South-East geopolitical region of Nigeria. For educational attainment, almost half $(45.8 \%)$ of the head of each household had primary education, 33\% had no formal education at all. While $18.8 \%$ had junior secondary education as against $2 \%$ with ordinary national diploma and vocational training respectively.

\section{Impact of VSLA on family wellbeing}

Participants highlighted the positive impact of the VSLA in areas such as schooling, nutrition, good shelter, health and ability to own and grow small businesses. One of the participants from ljebu-lfe noted that, "I sell small provision in front of my house which I started when I collected money from our association. It is small but I am happy that market is moving small small”. Another participant from ljebuIfe also stated that, "I fry akara, yam and potatoes at ljebu-Ife junction. I use the money I collected to start the business. My children eat well and we have food in the house". One of the participants from Owuljebu said:

My problem is that I worry too much, I was afraid when I collected the money because so many needs were on my head to solve. Thanks to the training from the people in SOS Children's Village, I closed my eyes and said this money must start one business for us in this family and that is how I started my kerosene business. This is over two years and am still doing well.

One of the participants from ljebu-lkija who was very vocal in the group said she is very happy that, "I can now pay school fees for my children as a result of the support from SOS Children's Village Programme Ogun and our Village Savings and Loan Association". Another participant from ljebu-lkija also noted that, "the Village Savings and Loan Association has helped me in repairing my licking roof and now we can sleep without waking up every night when it is raining...We suffered before this money came". Majority of the participants from the three communities all noted that the VSLA has helped them to support their children better in school through paying school fees and providing school materials. This was captured when one to the participant from ljebu-lkija noted that, "my children who were not going to school before are now going to school again, it is one of them that say he will not go again and wants to ride okada" They also noted that the VSLA has proved as a secured means of borrowing money without fear of threat like the case with microfinance bank. A participant from Owu-ljebu as to this regards stated thus:

Ewhoo! thank God for the VSLA, we all know ourselves and how to collect our money back. If it is bank, I will not even sleep when I collect their money because they will sell you and your property if you don't pay back.

They also agreed that with the establishment of small businesses such as engaging in garri (cassava flour) processing, they are able to make sales and increase their capital thus leading to their being able to pay back their loan on time. This was affirmed by a participant from ljebu-Ife who said that, "I go to ljebu-Imushin market every market day now because I have garri to sale...this is what the VSLA has done for me and for us"

\section{Role of SOS Children's Villages Nigeria in VSLA}

Women in the community knew they needed help but never knew how to come together to form a credit group that can help them support their 
families. The SOS Children's Villages Nigeria provided capacity building for the VSLA members which brought in changes and new perception on entrepreneurship development in rural communities. One of the participants from Owu-ljebu in trying to explain this said that:

...we used to do daily contribution and then collect back our money after some months, but this was not helping us because we use to spend all the money on so many things as nobody was training us on how to invest the money. Now I am happy because I am contributing money and SOS Children's Villages is providing us with training. The training is helping us on how to put that our money into profitable business so we can help our children and our family

Another participant from ljebu-Ife who was very excited with the positive impact on the VSLA has this to say:

I lost my husband a few years ago and was struggling to train my children. I was working then in one school where I receive small pay at the end of the month. This was not just enough to take care of my five children as I wanted all of them to go to school. Thank God for SOS Children's Villages Nigeria that brought us into their programme and little by little, they started training us and encouraging us to be part of the VSLA. I was happy with the savings. Today with what I have collected from the VSLA, I am almost completing my house which my husband could not do when he was alive.

The study also revealed that majority of the participant were better enlightened in areas such as entrepreneurship, savings culture, child development and care, and even community development projects. This was based on capacity building training given by the SOS Children's Villages Nigeria during the VSLA meeting and the monthly parenting skill training. Accordingly, many of the participated attributed their fear for not participating in savings group before now due to lack of guidance and training. One of the participants from ljebu-lkija said that, "the training SOS is giving us is what is helping us to know many things that we did not know before". Still another participant from Owu-lkija responded by saying, "Since SOS Children's Villages Nigeria came to teach us about the VSLA, for me the way I use money have changed. I put my money into business instead of keeping it and spending on things that will not help the family" Yet another participant from ljebu-Ife said,

... apart from the savings and doing business, SOS Children's Village Programme Ogun has made me to know the importance of health center. Before now, I use to spend so much money buying malaria drugs from the shops for my children. It was in one of the trainings that Mr... from SOS Children's Villages Nigeria told us that we can save better by blocking those places where we spent too much money on unnecessary things. He told us going to the community health center is cheaper and safer for us and our children...

Entrepreneurship development in rural communities using VSLA

Starting a small business and growing same is one area that is challenging in entrepreneurship development. One of the participants from Owuljebu stated thus;

I learned from the training given to us by SOS Children's Villages that you must plan your business. I don't have business before but now with the little money I collect from the group, I buy cassava tuber and peel with my children and them make garri which I sell in Imushin market.

Another from Ikeja-ljebu said that, "

I was told by SOS Chldren's Villages that you start planning on what you will do with the money even before you collect the money. I use to sell two gallon of kerosene in front of my house, I was doing that business for somebody. When I joined the VSLA, I took loan and now I buy more than four gallon to sell in Imushin market. The business is now my own, my gain has increased and I am even thinking of having a small drum or tank for storing kerosene so I can sell when kerosene is scare in the market.

One of the participants from ljebu-lfe had this to say,

I use to teach in a small primary school, but when my husband was murdered by unknown persons, I abandoned my work to take care of my children since that is all I have for now. I have been doing business before I joined the VSLA but how my business is moving now is not how it was moving before. The training given to us by SOS Children's Villages had helped me understand business skills and saving culture. The money I borrowed has helped to enlarge my business. I now buy more things to sell and also have plan on what to buy...

Challenges encountered by members in the VSLA groups

One of the challenges noted by majority of the participants is building of trust at the initial stage of the VSLA. A participant from Owu-ljebu noted that, "I was afraid to join the group because I know that some of us will say one thing and do another thing. I don't know who is who here because somebody can run away with the money and all of us will suffer". Another participant from ljebu-lfe said that, "since all of us are not from the same family and even from the same state, I was afraid that some people can collect the money and run away". This statement from a

http://aps.journals.ac.za 
participant from ljebu-lfe did not go down well with some participants who felt the participant was referring to them. In response, one of the participants from ljebu-Ife responded aggressively by saying that, "not everybody is a thief, with or without money some people will still steal". The aggression was even heightened when another participant from ljebu-lfe shouted pointing to some participant that spoke earlier and saying, "it is you people that will collect money and will not want to pay back at the agreed time, now you are the one calling people thief". Another challenge identified by the participants is defaulting in loan payment. This was noted when one of the participants from ljebu-lkija said, "when we started, some people were finding if difficult paying back their loan.... this was because nobody had money then. Now it is no longer like that". Another participant from the same communities contradicted the earlier statement by saying that, "people still take time to pay back loan, sometimes we have to talk and talk before they will pay back". Participants from Owu-ljebu and ljebu-ife also affirmed that some members still default in pay back loans as and when due. This they say is gradually being overcome with time but that it was a major challenge at the initial take off of the VSLA. Another challenge defined by the group was disagreement on what type of investment to put the money into while some participants were not favorably disposed to investment; others see it as a good opportunity that will yield returns. One of the participants from ljebuIkeja who was not favorably disposed to investment stated that, "I don't think is wise for one person to hold our money because if anything happens the person, who will you hold responsibly." Another who also supported the view said, "It is good to invest as we were taught in one of the classes but my fear is, will it not cause any problem in the future?" Despite the fear for investment, majority of the participants from the three communities agreed that investment will increase their initial capital and even help them to have more capital based on the interest that will accrue from the investment.

\section{Discussion}

This study investigated the promotion of entrepreneurship development by the SOS Children's Village Nigeria using the VSLA. Findings reveal that there are positive impacts on family wellbeing as reported by many of the participants from the three communities. This finding supports that of Kensenta \& Andre (20I5), who found that the VSLA positively impacted the lives of members. The loans taken by members according to Kensenta and Andre (2015) is mainly used to establish small businesses, provide basic needs, improve farming and livestock. Tamim (2015) also found that participation in social groups such as increases the levels of income and per-capita expenditure which can improve family wellbeing). This was also corroborated by Mochoge, (2016) on the positive impact of VSLA on women groups and improvement of family welfare. Other studies have shown that child vulnerability is brought to the barest minimal when families are able to provide basic needs for their children (NnamaOkechukwu, Anazonwu \& Okoye, 2018). The Village Savings and Loan Association has proven to be a sustainable means of empowering people especially women to have access to credit that can enable them start up small business and also take care of basic family needs (Karlan, et al., 2017; Kebede \& Butterfied, 2009; Khandker, 2005; Ogunlela \& Murkhar, 2009; Pitt, Chowdury, Millimet \& Khander, 2003). In affirmation, Sibomana and Shkla (2016) explained that VSLAs have proven to be very effective in accelerating growth and building local capacity. It has equally enabled members have access to highly responsive and safe financial services, upscale economic activities, improve household welfare, acquire business skills, educate their children, and improve the quality of their social lives both within the family and the surrounding community (Sibomana and Shkla, 2016).

The present study also found that women were more involved in the VSLA than men. This was however in contrast to Adofu, et al., (2010) findings which showed that men were more involved in the saving groups than women. The present study also found that most women who participated in the present study have low level education. This was in agreement with Kensenta \& Andre (20I5), who found that most savings groups' members were women with low levels of education which is a clear indicator of the scarcity of educated people in the rural areas. This according to the research seems be a trend in most developing countries where ruralurban migration for the educated youth is on the rise, hence leaving women, children, and elderly population in the villages. Tammin (2015) also found that women were more involved in saving groups than men. This according to the researcher could be as a way to create an environment for the females to participate in social activities which is the aim behind most village savings groups. Participation in VSLA have rural communities are developed when people are empowered. Loans from members from the savings group (SG) as revealed in the present study has supported small businesses in the rural communities thereby creating employment for families. Such support has also proved to be a way of building the coping skill of rural dwellers. Tamim (20I5) found that access to financial services to poor 
people through providing loans for the purpose of business or emergency cases can actually help people to engage in more businesses and believe that they can do more. Ledgerwood and Rasmussen (201 I) argue that savings groups such as the VSLA not only provide financial services; but they also significantly build social capital among group members as well as their financial capabilities. There are vast studies on the impact of VSLA in promoting family wellbeing, entrepreneurship development and financial services to the rural poor (Karlan et al., 2017; Rasmussen 20I3; Sarumathi \& Mohan, 20 I ; Schola. 20I5).

Other studies have however shown that although the VSLA procedure has proven its value in meeting needs of rural poor and promoting family welling, it still meets many challenges (Allen \& Staehle, 2009; Allen \& Panetta, 20I0; Hansen 20I2; Myrray \& Rosenburg, 2006). The findings of this present study revealed that one of the challenges faced by the saving group were building trust, defaulting in paying back loan and agreement on investment. This was in support of findings from Adofu et al (2010), that revealed that perceive lack of trust, fear of default, leadership structure and death of a member was a challenge for members in VSLA.

Following all these, the VSLA as a tool for promoting entrepreneurship development in rural communities has implication for social work profession in Nigeria. It is commendable to note that when a person sets out to help others, especially those most vulnerable to social problems, he or she assumes a serious responsibility (Sheafor \& Horejsi, 2006). Social work as a profession helps to shape and create environment that will be supportive and empowering thereby providing opportunity for vulnerable groups to develop the capacity to drive the change that they want to see (Ngwu, NnamaOkechukwu, \& Obasigwu, 2017). Creating awareness on VSLA will not only develop the capacity of vulnerable groups to income generating activities, but will also serve as a catalyst for entrepreneurship development in rural communities. For sustainability, there is therefore need to employ social workers in the Community Development Departments of local government headquarters in Nigeria who will thus network with other NGOs to identify unmet human needs. This will help in creating awareness at the local level on the gains of VSLA and also helps in the promotion of rural social work.

Working in rural communities with the rural poor will help social workers to begin to identify unmet human needs as well as the gaps in the service network that should be addressed in order to better serve the people in the community. This is the experience of the SOS Children's Villages Nigeria that has devoted time to empower rural people in rural 4909 communities so that labour migration, unemployment and child abandonment can be prevented. Working in rural communities with their social workers and field officers, the SOS Children's Villages Nigeria has continued to support the expansion of the VSLA. This is through strengthening the capacity of families on income generating activities as a strategy for continuous income flow to families even after they have exited the programme.

\section{Conclusion}

Poor families in most rural communities especially women in Nigeria still struggle to provide basic needs and send their children to school because they lack the means to do so. This no doubt increase child and family vulnerability especially when there are no income generating activities or steady means of providing for the basic needs of children and family. To address this challenge, there is need for social workers in Nigeria to provide professional support services through empowerment programme to vulnerable families. This is to help those in need develop the capacity to drive the change that they want to see. This will not only promote entrepreneurship development but will also increase the visibility of social work in rural areas. In summary, this study shares the experience of SOS Children's Villages Nigeria as an NGO that is promoting rural empowerment and entrepreneurship development in rural communities in Nigeria using the VSLA. Social workers in Nigeria therefore need to rise up to the need of building capacity of rural dwellers through the promotion of VSLA. Most rural dwellers are not aware of VSLA or how to come together to pull their resources together for a sustainable course. It is therefore important that social workers promote this awareness in rural areas so that the rural poor are able to grown small business that can support family and child development. This will help prevent unemployment, child abandonment and unnecessary labour migration.

\section{References}

Abubakari, A., Sadix, B. B. \& Keisan, Y. (20/4). Impact of village saving and loan association in the nutrition status of under-five children: $A$ case study of the Sissala West Distrist of Upper West Region. Pakistan Journal of Nutrition, 13 (7), 390396.

Adofu,I., Antai, E., \& Alabi, O. (2010). Informal savings mobilization and investment: $A$ case study of rotating saving and credit association (ROSCA) in Kogi State, Nigeria. Continental Journal of Social Sciences, 3, 7-I 7

Allen, H., \& Panetta, D. (20I0). Savings groups: What are they?. Washington DC: SEEP Network. 
Allen, H. \& Staehle, M. (2009). Programme guide, field operations manual, version 3.2,: VSL Associates. CARE International.

Appiah, S. \& Michael, A. (20/4). Multinomial logistic analysis of "Susu" contribution in Ghana. Journal of Economic and Social Development, I(I), 96-I05.

Atha (2017, March 27). Sustainable Livelihoods Framework. Retrieved from ATHA:

http://atha.se/content/sustainable-livelihoodsframework.

Anyango,E., Esipisu, E., Opoku, L., Johnson, S., Malkamaki, M., \& Musoke, C (2007). Village savings and loan associations experience from Zanzibar. Small Enterprise Development., I8(I), II-24

Badero, I.O., Yusuf, K. E \& Anoile, D. (2016). Adherence to cooperative principles among agricultural cooperative in Oyo Sate Nigeria. Journal of Agric Education, 20(I), |42-I5 I

Beyene, N. L. (20I8). Assessment of the effectiveness of the Village Savings and Loan Association (VSLA) in poverty reduction in Hawassa Ethopia. A mini thesis submitted to the Institute of Social Development, Faculty of Economic and Management Science, University of Western Cape, for the award of masters of Art Degree in Development Studies.

Breza, E., \& Chandrasekher, A.G.(2019). Social network, reputation and commitment: Evidence form a saving monitor experiment. Econometrics 81 (I), I75-216

Burnice, A., Funmagali, L., Martin, T., Field, S., \& Rutherford, D (2014) Can the village savings and loan groups be a potential tool in the malnutrition fight? Mixed methods finding from Mozambiue. Children and Youth Services Review, 47(2), II3120

CARE (20I3). Connecting the world's poorest people to the global economy. new models for linking informal savings groups to formal financial services. Retrieved from CARE:

http://www.care.org/sites/default/files/documents/EC ON-20I3-CARE-\%20Connecting-the-worldspoorest_0.pdf

CARE (20I4). Village saving and loans associations. Kampala: CARE International in Uganda.

CARE (2017). Research on the role of village savings and loan association and community based saving groups in household's resilience. CARE :Afghanistan

Catholic Relief Services (2017, April 15). Lives and Livelihoods: How Savings groups transform lives. Why Savings and Internal Lending Communities (SILC)? Retrieved from: http://www.crs.org/our-work- overseas/program-areas/microfinance/silc$\mathrm{road} / \mathrm{impact}$

Champchesnel,M.,Fioekon, C., Sanda, H.B.,Lavaur,A \& Mayans, $J$ (2017). Village savings and loan association: An approach adapted to the poorest household. Solidarity International.

Gert. G. \& Kharas, H. (20|8). Leave no country behind ending poverty in the toughest places. Global economy \& development working paper II0. Available: https://www.brookings.edu/research/leave-nocountry-behind/

Gert, G \& Kharas, H. (20I8). The road to ending poverty runs through 31 severely off track countries. Available at: https://www.brookings.edu/blog/futuredevelopment/2018/02/13/the-road-to-ending poverty-runs-through-3I-severely-off-track countries/

Hassan, R., \& Birungi, P. (20II). Social capital and poverty in Uganda. Development Southern Africa, 28(I), 19-37.

Hendrick, L \& Chidiae. S (20II). Village savings and loan association: A pathway to financial inclusion for Africa poorest household. 201I Global Microcredit Summit Commissioned Work Paper, November 14-17, Valladolid, Spain

Hinson, M,.Oduro,E.,Cottreli, B.(2017). Village savings and loan association: A case study of Porococo Ghana.CARE: JMK consulting

Jackson, H. L.(20I6). Dynamics and sustainability of Village Savings and Loan Association: A Case study of Samesame District Tanzania. A Dissertation submitted in partial fulfillment of the degree and master of Arts in Rural Development of Sokoine, University of Agriculture Morogove Tanzania.

Karlan, D., Savonittes, B.,Thuysbaert, B., \& Udry, C (20I7). Impact of the village savings and loan association on the lives of the poor. Proceeding of the National Academy of Science of the United State of America, I I (2), 30 I9-3064.

Kebede, W. \& Butterfield, A.K. (2009). Social networks among poor women in Ethiopia", International Social Work, 52(3), 357-74.

Kesanta, James \& Andre, Billy (2015) impact of women empowered through community savings groups on the wellbeing of their families: A study from Mgubwe, Tanzania," Interdisciplinary Journal of Best Practices in Global Development. http://knowledge.e.southern.edu/ijbpgd/vol I/iss I/ 4

Khandker, S.R. (2005). Microfinance and poverty: evidence using panel data from Bangladesh. The World Bank Economic Review, 19,263-286. 
Kiboro, C.N., Gakuru, O. N., Misaro, J. \& Mwangi, S. W. (20|4). Role of social work in minimizing sexual and gender inequalities. Research on Humanities and Social Sciences, 4 (I4), 84-88.

Ksoll C, Bie Lilleør H, Lønborg JH \& Rasmussen O.D, (2016). Impact of village savings and loans associations: Evidence from a cluster randomized trial. Journal of Development Economics, I20, 7085.

Krantz, L. (200I).The sustainable livelihood approach to poverty reduction. Swedish International Development Cooperation Agency, Division for Policy and Socio-Economic Analysis

Lonborg J. H., \& Rasmussen, O. D. (20I4). Can microfinance reach the poorest:evidence from a community managed microfinance intervention. World Development, 64, 460-472.

Mochoge, N. W. (2016). Effects of village savings and loans on rural women livelihood outomes among women groups in Kisii County. Masters of Science Finance Degree, School of Business.

Musinggusi, L. K (20।6). The role of social network in savings groups: Insights from village savings and loan associatiom in Luwero Uganda. Community Development Journal, 5 I (4), 499-5I6

Mwansakilwa, C., Tembo, G., Zulu, M.M., \& Mukata, W.(2017). Village fsavings and loan association and household welfare: Evidence from Eastern and Western Zambia. African Journal of Agricultural and Resources Economic, I2(I), 85-97

Ngwu, C., Nnama-Okechukwu, C. U., \& Obasigwu, I. (20I7). Social work with orphans' ad vulnerable children. In Okoye, U O., Chukwu, N. \& Agwu, P. (eds). Social work in Nigeria: Book of readings (Chapter 17, p. 212). Enugu: University of Nigeria Press.

Nnama-Okechukwu, C.U., Chukwu, N. E., \& Ekoh, C. (2017). Social work with women and children In Okoye, U O., Chukwu, N. \& Agwu, P. (eds). Social work in Nigeria: Book of readings (Chapter 13, p. 166). Enugu: University of Nigeria Press.

Nnama-Okechukwu, C. U., Anazonwu, N.P., and Okoye, U.O. (20I8). Vulnerable children, alternative care system and placement decision in Nigeria: In who's best interest. Africa Population Studies, 32(2), 42I 5-4227

Ogunlela, Y. 7 Mukhtar, A. (2009), "Gender issues in agriculture and rural development in Nigeria: The role of women, Humanity \& Social Science Journal, 4(I), 19-30.

Ogunrinola, O. (20II). Social capital and earnings distribution among female micro-entreprenurs in rural Nigeria. African Journal of Economic and Management Studies, 2(I), 94-II 3

Otto, G., \& Ukpere, W.(20II). Credit and thrift cooperatives in Nigeria: A potential source of capital formation and employment. African Journal of Business Management, 5(I4), 5675-5680.

Okoye, U. O. (20I3) 'Trend and Challenges in Social Work Practice in Nigeria, in Cree V.E. (eds). Becoming a Social Worker: Global Narrative London, Uk; Routledge. Taylor and Francis Group, pp 149-157

Okoye, U.O. (September, 20I7). Fostering family resilience in Nigeria's recessed economy: challenges, options and academic perspectives. Keynote address presented at the 18th Annual International Home Economics Research Association of Nigeria (HERAN) Conference holding at the Hall of Fame, University of Nigeria, Nsukka, on the theme Family survival in a recessed economy: Viable options and Research Perspectives, 29th September to 2nd October, 2017.

Pitt, M. M., Khandker, S. R., Chowdury, O.H. \& Millimet, D.L. (2003). Credit Programs for the poor and the health status of children in rural Bangladesh. International Economic Review 44, 87-II8.

Rasmussen, O. D. (2013). The Economics of Savings and Loan Associations. Evidence from a Randomized Control Trial in Malawi. University of Southern Denmark: Department of Business and Economics.

Schola, B. K. (20/5). A case study of a village saving and loan association and its relation to poverty reduction among rural households in Kyabakara, Uganda. Agder: University of Agder. Department of Global Development and Planning.

Sibomana, J.P. .\& Shuwla, C. (20/6). effect of village savings and loan association on small and medium enterprise(sME) growth in Ruwanda: Survey of Kayoriza District. International Journal of Buisness and Management Review, 4(3), 57-79

Surmont, T. (2017) Analyzing village savings and loan Association through the sustainable livelihood Approach. A case study in Karabole District. Master Dissertation

Tamim, K. A. (20I5). The role of social capital in poverty reduction: $A$ case study of saving groups in the Parwan province of Afghanistan. Thesis Presented to the Higher Degree Committee of Ritsumeikan Asia Pacific University in Partial Fulfillment of the Requirement for the Degree of Master of Science in International Cooperation Policy.

UNICEF (20I7). UNICEF annual report for Nigeria

United Nations (20I6). Sustainable development goal: Transforming our world-the 2030 agenda for sustainable development. Available http://sustainabledevelopment.un.org/topics/sustai nabledevelomentgoals. Accessed 28. June 2019 
Uruakpa, P. C (2018). Do informal financial institution in Nigeria matter for saving, investment and growth. International Jouranla of Banking and Finance 4 (3), 25-40

Village Saving Associates (20/4). Available at http://www.vsla.net/ accessed on June 28th, 2019.
World Bank (2016). Understanding poverty Available: http://www.worldbank.org/en/topic/poverty/over view, Accessed on June 28th, 2019

Yusf, N., ljaiya, G. T \& ljaiya, M. A (2009). Informal financial institution and poverty reduction in the informal sector of Offa town, Kwara Sate: A case study of Rotating Savings and Credit Association (ROSCAs). Journal of Social Sciences, 20(I),7I-8I. 